Abstracta Iranica Abstracta Iranica

Revue bibliographique pour le domaine irano-aryen

Volume 34-35-36 | 2017

Comptes rendus des publications de 2011-2013

\title{
Florence Jullien. Abraham le Grand et la réforme du monachisme au Moyen-Orient. Regard sur quelques pratiques spirituelles
}

Marie-Joseph Pierre

\section{(2) OpenEdition \\ Journals}

Édition électronique

URL : http://journals.openedition.org/abstractairanica/41930

DOI : 10.4000/abstractairanica.41930

ISSN : 1961-960X

Éditeur :

CNRS (UMR 7528 Mondes iraniens et indiens), Éditions de l'IFRI

Référence électronique

Marie-Joseph Pierre, «Florence Jullien. Abraham le Grand et la réforme du monachisme au Moyen-Orient. Regard sur quelques pratiques spirituelles », Abstracta Iranica [En ligne], Volume 34-35-36 | 2017, document 23, mis en ligne le 30 décembre 2016, consulté le 02 octobre 2020. URL : http:// journals.openedition.org/abstractairanica/41930; DOI : https://doi.org/10.4000/abstractairanica. 41930

Ce document a été généré automatiquement le 2 octobre 2020.

Tous droits réservés 


\title{
Florence Jullien. Abraham le Grand et la réforme du monachisme au Moyen- Orient. Regard sur quelques pratiques spirituelles
}

\author{
Marie-Joseph Pierre
}

\section{RÉFÉRENCE}

Florence Jullien. « Abraham le Grand et la réforme du monachisme au Moyen-Orient. Regard sur quelques pratiques spirituelles ». Collectanea Cisterciensia, 74/4, 2012, p. 373-384.

1 Cette réflexion est destinée à faire connaître à un large public, quelque peu familier des questions monastiques occidentales, la réforme conduite au sein du mouvement monastique syriaque oriental par Abraham de Kaškar ( $† 586 / 588)$. Cette présentation circonstanciée contribue à mieux faire comprendre les fondements et les circonstances du renouveau suscité par cette œuvre pour le monachisme dyophysite dès la seconde moitié du $\mathrm{VI}^{\mathrm{e}} \mathrm{s}$., mais aussi la création des nombreuses fondations comme autant de pôles d'excellence en territoire iranien. 


\section{AUTEURS}

\section{MARIE-JOSEPH PIERRE}

Directrice d'Études honoraire, EPHE 